\title{
Pharmacologic Effects of Autacoids on Subsets of T Cells

\author{
Regulation of Expression/Function of Histamine-2 Receptors by a Subset of Suppressor Cells
}

Manzoor M. Khan, Paolo Sansoni, Edgar G. Engleman, and Kenneth L. Melmon

Departments of Medicine, Pharmacology and Pathology, Stanford University School of Medicine, Stanford, California 94305

\begin{abstract}
Autacoids (principally histamine, beta adrenergic catecholamines, and prostaglandins $E$ and $A$ ) have only recently been recognized as substantive moderators of a number of immune functions. If autacoids are to be considered as potential therapeutic immunomodulators, it is necessary to understand their effects on subsets of $T$ cells while they are and are not in contact with each other. This report demonstrates that autacoid receptors are nonrandomly distributed on phenotypically and functionally distinct subsets of human $T$ cells. Each human $T$ cell subset responded to both histamine and isoproterenol, but the dose response curve and maximal efficacy varied widely between the subsets. The suppressor $T$ cells were more responsive to both histamine and isoproterenol than helper/ inducer $T$ cells $\left(T_{H}\right)$ or cytotoxic $T$ cells $\left(T_{c}\right)$. We found that after mitogenic stimulation the response to histamine, but not isoproterenol, was greatly increased only in $T_{H}\left(\right.$ Leu $3^{+}$) and $T_{c}\left(\right.$ Leu $2^{+}, 9.3^{+}$) subsets, and that this effect may be regulated by suppressor $T$ cells (Leu $2^{+}, 9.3^{-}$). The dramatic rise in cAMP accumulation in response to histamine in mitogentreated $T_{H}$ and $T_{c}$ was totally blocked by an $H_{2}$ antagonist (cimetidine), but not by an $\mathrm{H}_{1}$ antagonist (mepyramine). These findings indicate interdependence of $(a)$ immunologically uncommitted subsets in their response to selected drugs, and (b) control of basal- and autacoid-induced cAMP production, as well as $(c)$ increased qualitative and quantitative selectivity, which is caused by mitogen. If we had performed these experiments only on unseparated cells we would not have observed the remarkable selectivity of autacoid effects on subsets of $T$. cells.
\end{abstract}

\section{Introduction}

Autacoids, such as beta adrenergic catecholamines and histamine, are mediators and modulators of complex in vivo and in vitro models of inflammation and have lately become known as moderators of immunity (1-5). These substances are made during different phases of response to antigen and are able, directly and indirectly, to affect further responses to antigen. It is possible that the concentration of autacoids in tissue during inflammation and immune response is sufficient to allow them to modify the functions of a number of cells

Address correspondence to Dr. Melmon, Department of Medicine. Dr. Sansoni's present address is Istituto di Clinica Medica Generale, Universita degli studi di Parma, Via Gramsci 14, Parma, Italy.

Received for publication 25 July 1984 and in revised form 22 January 1985.

J. Clin. Invest.

(C) The American Society for Clinical Investigation, Inc. $0021-9738 / 85 / 05 / 1578 / 06 \quad \$ 1.00$

Volume 75, May 1985, 1578-1583 that control and express both humoral and cell-mediated immunity. Histamine and beta adrenergic catecholamines modulate the activity of immunocompetent cells via specific receptors on the cell surface, but their precise distribution on subsets of $T$ cells and the effect that different stages of development of the immune response have on them has not been determined. After binding to specific receptors on the lymphocytes, beta adrenergic agonists and histamine activate membrane adenylate cyclase and initiate the accumulation of intracellular adenosine $3^{\prime}, 5^{\prime}$ monophosphate (cyclic AMP). Considerable work has described immune modulatory effects caused by cAMP (6-8), but we do not know whether all of the effects of autacoids that modulate immunity work only through this second messenger or if there are alternative or additional mechanisms of action.

This report demonstrates the distinct effects of autacoids on phenotypically and functionally distinct subsets of human $T$ cells. We demonstrate that autacoid receptors are distributed nonrandomly on subsets of $T$ cells and that mitogens selectively affect subsets of $\mathrm{T}$ cells by stimulating the cells response to the ligands, presumably via effects on receptor availability. Expression or function of $\mathrm{H}_{2}$ receptors on Leu $3^{+}$(helper/inducer T cells $\left.\left[T_{H}\right]\right)^{1}$ and Leu $2^{+}, 9.3^{+}$(cytotoxic $T$ cells $\left[T_{c}\right]$ ) subsets may be regulated by Leu $2^{+}, 9.3^{-}$(suppressor $T$ cells $\left[T_{s}\right]$ ) subsets.

\section{Methods}

Isolation of subsets of lymphocytes from human peripheral blood. Mononuclear cells from peripheral blood of healthy volunteers were obtained by ficoll-hypaque gradient centrifugation of fresh defibrinated blood. $T$ cells and non-T cells were isolated by a single step rosetting method using aminoethyesothiouroniumbromide hydrobromide (Sigma Chemical Co., St. Louis, MO)-treated sheep erythrocytes (SRBC). Rosette-forming $T$ cells were separated on a second ficoll-hypaque gradient and freed from the SRBC by hypotonic lysis. The $T$ cell fraction contained $>95 \%$ E-rosette forming cells. The non-T cell fraction included $40-50 \%$ surface Ig-positive B cells, $30-50 \%$ alpha naphthyl acetate esterase-positive plastic adherent monocytes, and 5$10 \%$ nonadherent, nonsurface Ig-negative non-T and non-B cells.

Purified subsets of $T$ cells were obtained by a panning technique which permitted the fractionation of fresh T cells into Leu $3^{+}$and Leu $3^{-}\left(2^{+}\right)$subpopulations. Indirect immunofluorescence and cell sorter analysis of Leu 3 panned cells showed that $<2 \%$ of the unbound cells and $>95 \%$ of the bound cells were Leu $3^{+}$. Similar subset purity was achieved when anti-Leu 2 was used as the panning antibody. The Leu $2^{+}\left(3^{-}\right)$population was further separated into $9.3^{+}$and $9.3^{-}$subsets by panning with the 9.3 antibody. Cytofluorographic analysis of the 9.3subpopulation of Leu $2^{+}$cells showed that $<3 \%$ of the unbound cells were $9.3^{+}$compared with $>95 \%$ of the bound cells $(9-11)$.

Drugs and chemicals. Histamine dihydrochloride, cimetidine, and

1. Abbreviations used in this paper: Con A, concanavalin A; PHA, phytohemagglutinin; SRBC, sheep erythrocytes; $T_{c}$, cytotoxic $T$ cells; $T_{H}$, helper/inducer $T$ cells; $T_{s}$, suppressor $T$ cells. 
mepyramine maleate were purchased from Sigma Chemical Co. and forskolin was purchased from Calbiochem-Behring Corp. (La Jolla, CA). Phytohemagglutinin (PHA)-P was purchased from Burroughs Wellcome and Co. (Beckenham, England) and concanavalin A (Con A) from Pharmacia Fine Chemicals, Inc. (Uppsala, Sweden).

Measurement of intracellular cAMP after treatment with agonists. Subsets of $T$ cells were suspended in phosphate-buffered saline (PBS) and were incubated with $10 \mathrm{mM}$ isobutyl methyl xanthine at a final concentration of $20 \mu \mathrm{M}$ for $10 \mathrm{~min}$ at $37^{\circ} \mathrm{C}$. Thereafter, $2 \times 10^{5}$ cells were incubated with histamine $\left(10^{-2}-10^{-5} \mathrm{M}\right)$ or isoproterenol $\left(10^{-4}\right.$ $10^{-7} \mathrm{M}$ ) in a final volume of $250 \mu \mathrm{l}$ for $1 \mathrm{~min}$ at $37^{\circ} \mathrm{C}$ with continuous shaking. Immediately thereafter $1 \mathrm{~N} \mathrm{HCl}$ was added to a final concentration of $10 \%$ and the tubes were put on ice. The samples were neutralized with $2 \mathrm{~N} \mathrm{NaOH}$. Acetylation of samples as well as cAMP standards was performed by addition of $10 \mu \mathrm{l}$ of triethylamine and acetic anhydride (2:1). Acetylation improved the sensitivity of the assay by $\sim 50-100$-fold. Radioimmunoassay was performed by the method of Brooker et al. (12).

Response to agonists after stimulation of subsets of $T$ cells with phytohemagglutinin (PHA). Subsets of $\mathrm{T}$ cells were suspended to $1 \times 10^{6} / \mathrm{ml}$ in RPMI $1640,25 \mathrm{mM}$ Hepes, $2 \mathrm{mM}$ L-glutamine, 100 $\mu \mathrm{g} / \mathrm{ml}$ streptomycin, $100 \mathrm{U} / \mathrm{ml}$ penicillin (all from Gibco Laboratories, Grand Island, NY), and 10\% heat inactivated pooled human serum. The cells were incubated with $1 \mu \mathrm{g} / \mathrm{ml} \mathrm{PHA}$ at $37^{\circ} \mathrm{C}$ in an atmosphere of $5 \% \mathrm{CO}_{2}, 95 \% \mathrm{O}_{2}$. After $24,48,72$, and $96 \mathrm{~h}$ of stimulation with PHA, the cells were centrifuged and resuspended in PBS to a final concentration of $1 \times 10^{6}$ cells $/ \mathrm{ml}$. Resting cells as well as those stimulated with PHA $\left(2 \times 10^{5}\right)$ were incubated with histamine $\left(10^{-4} \mathrm{M}\right)$ or isoproterenol $\left(10^{-5} \mathrm{M}\right)$, and intracellular accumulation of cAMP was measured as described.

Response to histamine, isoproterenol, and forskolin after Con A stimulation in subsets of $T$ cells. After 24,48 , and $96 \mathrm{~h}$ of stimulation with Con $A(25 \mu \mathrm{g} / \mathrm{ml})$ and monocytes, under culture conditions similar to those described for PHA, the cells were centrifuged and resuspended in PBS to a final concentration of $1 \times 10^{6}$ cells $/ \mathrm{ml}$. Resting cells as well as cells stimulated with Con A were incubated with histamine $\left(10^{-4} \mathrm{M}\right)$, isoproterenol $\left(10^{-5} \mathrm{M}\right)$, or forskolin $\left(10^{-5}\right.$ M). Intracellular accumulation of cAMP was measured as described above.

Blocking the effects of histamine by $\mathrm{H}_{1}$ and $\mathrm{H}_{2}$ antagonists in subsets of $T$ cells. Subsets of $T$ cells were incubated with an $H_{1}$ antagonist, mepyramine $\left(10^{-6} \mathrm{M}\right)$, and an $\mathrm{H}_{2}$ antagonist, cimetidine $\left(10^{-5} \mathrm{M}\right)$, in the presence of histamine $\left(10^{-4} \mathrm{M}\right)$ to determine if intracellular accumulation of cAMP in resting as well as stimulated cells was mediated by $\mathrm{H}_{1}$ or $\mathrm{H}_{2}$ receptors. These concentrations of antagonists were chosen because they specifically saturated the $H_{1}$ and $\mathrm{H}_{2}$ receptors (13-15).

\section{Results}

Basal intracellular cAMP levels in subsets of resting $T$ cells. As shown in Fig. $1 A$, basal cAMP levels varied between subpopulations of fresh $\mathrm{T}$ cells. The Leu $3^{+}$subset (helper/ inducer cells) had lower basal cAMP than any other subset including the mixture of Leu $2^{+}$cells $(P<0.05, n=6)$. When Leu $2^{+}$cells were fractionated with 9.3 antibody into separate subpopulations, the basal cAMP levels among Leu $2^{+}, 9.3^{+}$ cells $\left(\mathrm{T}_{\mathrm{c}}\right)$ increased significantly $(P<0.05, n=6)$, whereas the basal cAMP levels of the Leu $2^{+}, 9.3^{-}$cells (suppressor $T$ cells $\left[\mathrm{T}_{\mathrm{s}}\right]$ ) did not differ from the mixture of Leu $2^{+}, 9.3^{+}$cells $\left(\mathrm{T}_{\mathrm{c}}\right)$ with Leu $2^{+}, 9.3^{-}$cells $\left(T_{s}\right)$. The addition of excess 9.3 antibody to unseparated Leu $2^{+}$cells did not alter basal cAMP levels, which suggested that the separating antibody did not have any effect on them.

Accumulation of intracellular cAMP in subsets of $T$ cells after their treatment with histamine or isoproterenol. Leu $3^{+}$, Leu $2^{+}, 9.3^{+}$, and Leu $2^{+}, 9.3^{-}$cells were incubated with

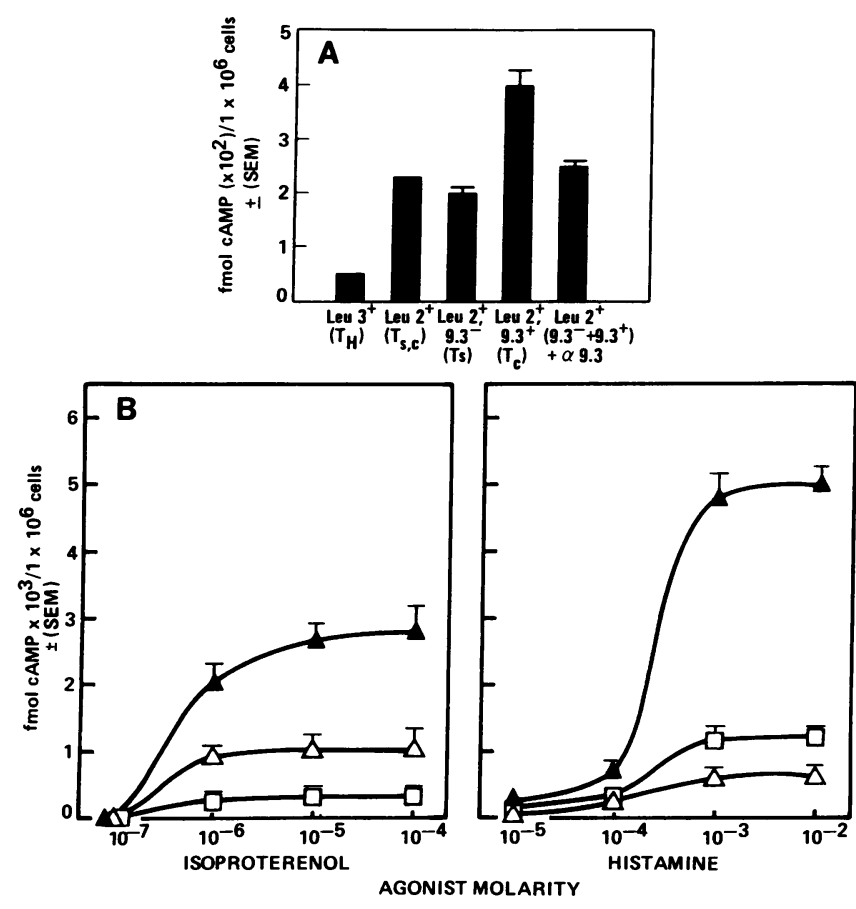

Figure 1. A shows the resting cAMP levels in subsets of T cells measured by radioimmunoassay. Basal cAMP levels are significantly different $(P<0.05)$ in Leu $3^{+}$cells vs. Leu $2^{+}$cells and in Leu $2^{+}$, $9.3^{-}$cells vs. Leu $2^{+}, 9.3^{+}$cells. Values are means \pm SEM and show one representative experiment out of six with comparable results. $B$ shows autacoid-mediated intracellular accumulation of cAMP in Leu $3^{+}(\square)$, Leu $2^{+}, 9.3^{-}(\Delta)$, and Leu $2^{+}, 9.3^{+}(\Delta)$ subsets. Values are means of triplicates $\pm S E M$ in one representative experiment out of four.

histamine or isoproterenol for $1 \mathrm{~min}$ before the measurement of intracellular cAMP. Net accumulation of cAMP was determined by subtracting the basal levels from total stimulated intracellular CAMP (12). One representative experiment out of four is shown in Fig. 1. Each human $T$ cell subset responded to both histamine and isoproterenol, but the dose-response curves and maximal efficacy varied widely between the subsets. The Leu $2^{+}, 9.3^{-}$cells were more responsive to both histamine and isoproterenol than either Leu $3^{+}$or Leu $2^{+}, 9.3^{+}$subsets. The Leu $3^{+}$subset was a significantly better responder to histamine than Leu $2^{+}, 9.3^{+}$cells $(P<0.05, n=4)$, but the effects of isoproterenol were greater in Leu $2^{+}, 9.3^{+}$cells than in Leu $3^{+}$cells $(P<0.05, n=4)$. The simultaneous presence of the antibody which was used to separate the cells (Leu $3^{+}$, $9.3^{+}$) did not alter the agonist induced response (data not shown).

Effects of agonists on subsets of $T$ cells stimulated with $P H A$. To determine if activated $\mathrm{T}$ cells differed from resting cells in their response to autacoids, fresh $T$ cells and $T$ cell subsets were each incubated with PHA $(1 \mu \mathrm{g} / \mathrm{ml})$ and the activated cells were harvested after $72 \mathrm{~h}$. Cells were then treated with agonists and levels of cAMP were measured. The basal cAMP levels were unchanged after the incubation with PHA (Fig. 2). The mitogen induced a slight increase in the maximal response to histamine in the mixture of $T$ cells, but the response to isoproterenol remained unchanged. When the Leu $3^{+}$cells were separated from total $T$ cells, and treated separately with PHA, they showed a markedly enhanced 


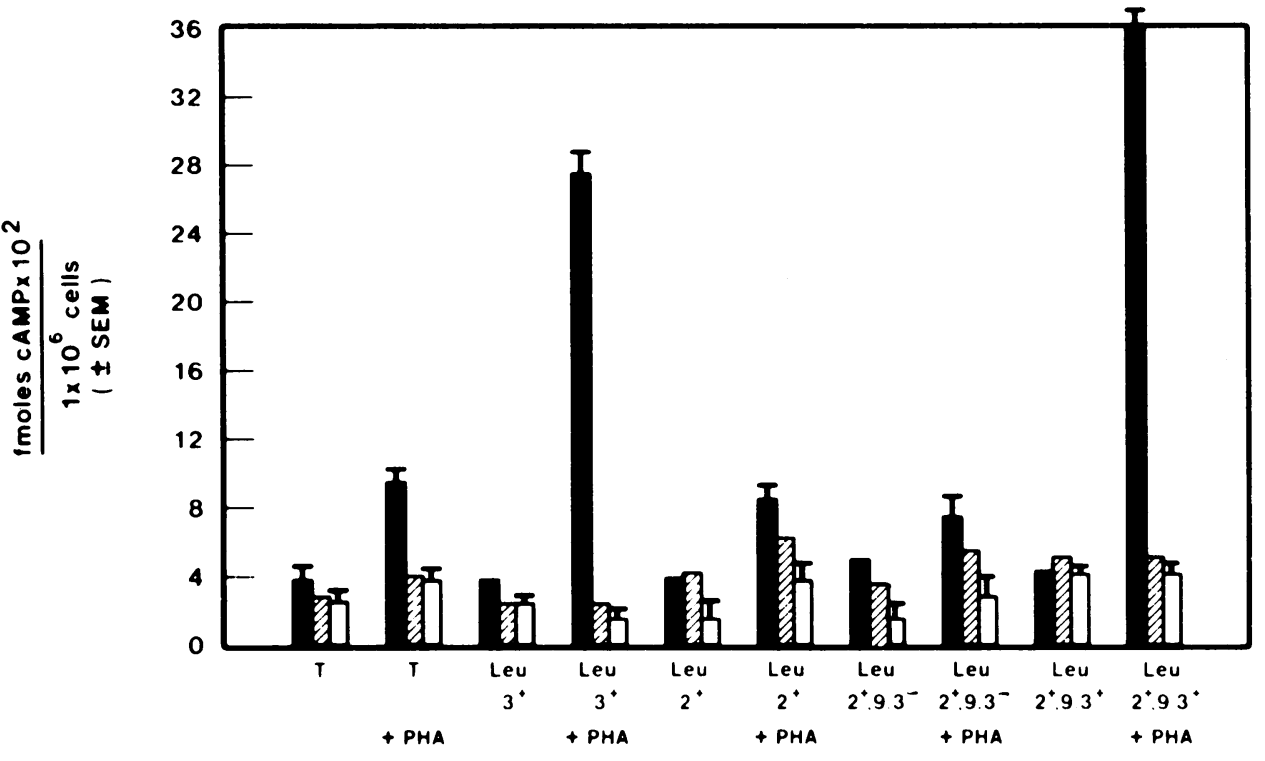

Figure 2. Intracellular accumulation of cAMP in subsets of $\mathrm{T}$ cells after their treatment with histamine $10^{-4}$ $\mathbf{M}(\mathbf{(})$ and isoproterenol $10^{-5} \mathrm{M} \mathrm{(घ)}$ is shown after stimulation of subsets of T cells with PHA $(1 \mu \mathrm{g} / \mathrm{ml})$. Open bars represent basal levels of cAMP. Values are means of triplicates \pm SEM in one representative experiment out of four experiments. Levels of CAMP in Leu $3^{+}$and Leu $2^{+}, 9.3^{+}$are significantly different $(P$ $<0.01)$ in PHA treated vs. untreated cells. response to histamine and no change in response to isoproterenol. Histamine did not excessively stimulate cAMP levels in PHA-treated Leu $2^{+}$cells $\left(T_{s, c}\right)$ or Leu $2^{+}, 9.3^{-}$cells $\left(T_{s}\right)$ above the levels seen in populations incubated in the absence of PHA. On the other hand, Leu $2^{+}, 9.3^{+}$cells stimulated with PHA in the absence of Leu $2^{+}, 9.3^{-}$cells responded at least 15-20-fold more after stimulation with PHA than before. The change in responsiveness appeared to be agonist specific. There were no mitogen-induced changes in the response of any subset to isoproterenol (Fig. 2), whereas all subsets responded to forskolin $\left(10^{-5} \mathrm{M}\right)$, which demonstrated a severalfold increase in intracellular accumulation of cAMP (data not shown). $T_{s}$ cells affected the $T_{c}$ cells response to PHA-histamine stimulation. In addition, the mixture of $T_{c}$ and $T_{s}$ cells was a key factor in the response of $T_{H}$ cells to PHA-histamine stimulation.

The kinetics of PHA stimulation on histamine-induced intracellular accumulation of cAMP is shown in Fig. 3. After $24 \mathrm{~h}$ of incubation of the subsets of T cells with PHA, only $T_{c}$ cells showed increased responses to histamine, reaching a level $300 \%$ greater than before the cells were treated with PHA. After $48 \mathrm{~h}$, PHA induced a 500\% enhancement of the response to histamine in $T_{H}$. The enhancement was not stable in $T_{H}$ cells and diminished over the next $2 \mathrm{~d}$. No change in

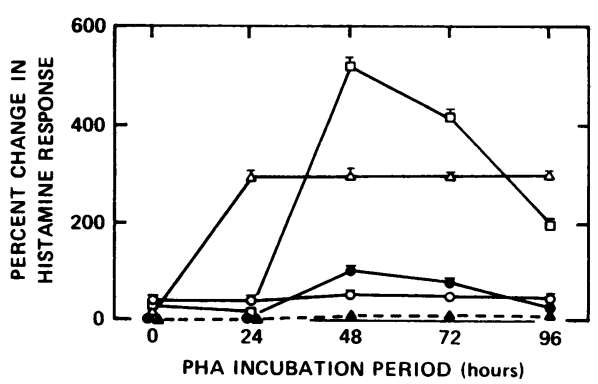

Figure 3. This figure represents the kinetics of PHA $(1 \mu \mathrm{g} / \mathrm{ml})$ stimulation on histamine $\left(10^{-4} \mathrm{M}\right)$-induced intracellular accumulation of cAMP in total T (๑), Leu $3^{+}($( $)$, Leu $2^{+}(0)$, Leu $2^{+}, 9.3^{-}(\Delta)$, and Leu $2^{+}, 9.3^{+}(\Delta)$ cells. One representative experiment from four experiments is shown. response to autacoids was seen in $T_{s}$ cells or in a mixture of $T_{s}$ and $T_{c}$ cells, which suggested that $T_{s}$ cells prevent $T_{c}$ cells from an augmented response to histamine. Experiments are in progress to determine the extent of this interaction. In unfractionated total $T$ cells a slight but definite enhancement of response was observed that started after $48 \mathrm{~h}$, persisted for $72 \mathrm{~h}$, and returned to baseline at $96 \mathrm{~h}$.

This variety of altered responses to histamine after stimulation of $T$ cell subsets with PHA was not paralleled in response to isoproterenol (data not shown) even though the cells responded to isoproterenol before and after PHA stimulation.

Effects of agonists on subsets of $T$ cells stimulated with Con $A$. The maximum responses of Con A-treated subsets of $T$ cells to histamine and isoproterenol are shown in Fig. 4. Forskolin $\left(10^{-5} \mathrm{M}\right)$ was used to stimulate cellular adenylate cyclase maximally in order to determine the true maximal base upon which the autacoids could act. As shown in Fig. 4, the degree of adenylate cyclase stimulation was higher with forskolin as compared to histamine or isoproterenol. This indicated that histamine or a beta adrenergic agonist, isoproterenol, could only stimulate cAMP up to a certain limit, even though more adenylate cyclase was still available. After $48 \mathrm{~h}$ of incubation with Con A, forskolin-induced cyclic AMP accumulation was enhanced in all subsets. But as was the case with PHA stimulation, Con A increased histamine-induced enhanced production only in $T_{H}$ and $T_{c}$ cells. Once again the responses to histamine but not isoproterenol were augmented. The kinetics of the augmented response were specific to given subsets and generally paralleled the response conditioned by PHA. The basal cAMP levels in all subsets were unaffected by Con A.

Blocking the effect of histamine by $H_{1}$ and $H_{2}$ antagonists. The dramatic rise in cAMP accumulation in response to histamine in mitogen (PHA)-treated $T_{H}$ and $T_{c}$ cells was totally (Fig. 5) and competitively blocked by cimetidine, an $\mathbf{H}_{2}$ antagonist. An $\mathrm{H}_{1}$ receptor antagonist, mepyramine, did not modify the histamine-induced changes in cAMP within resting or mitogen-stimulated cells (Fig. 5). The histamine antagonists did not block forskolin-induced cAMP accumulation (data not shown) in any subset of $T$ cells. 


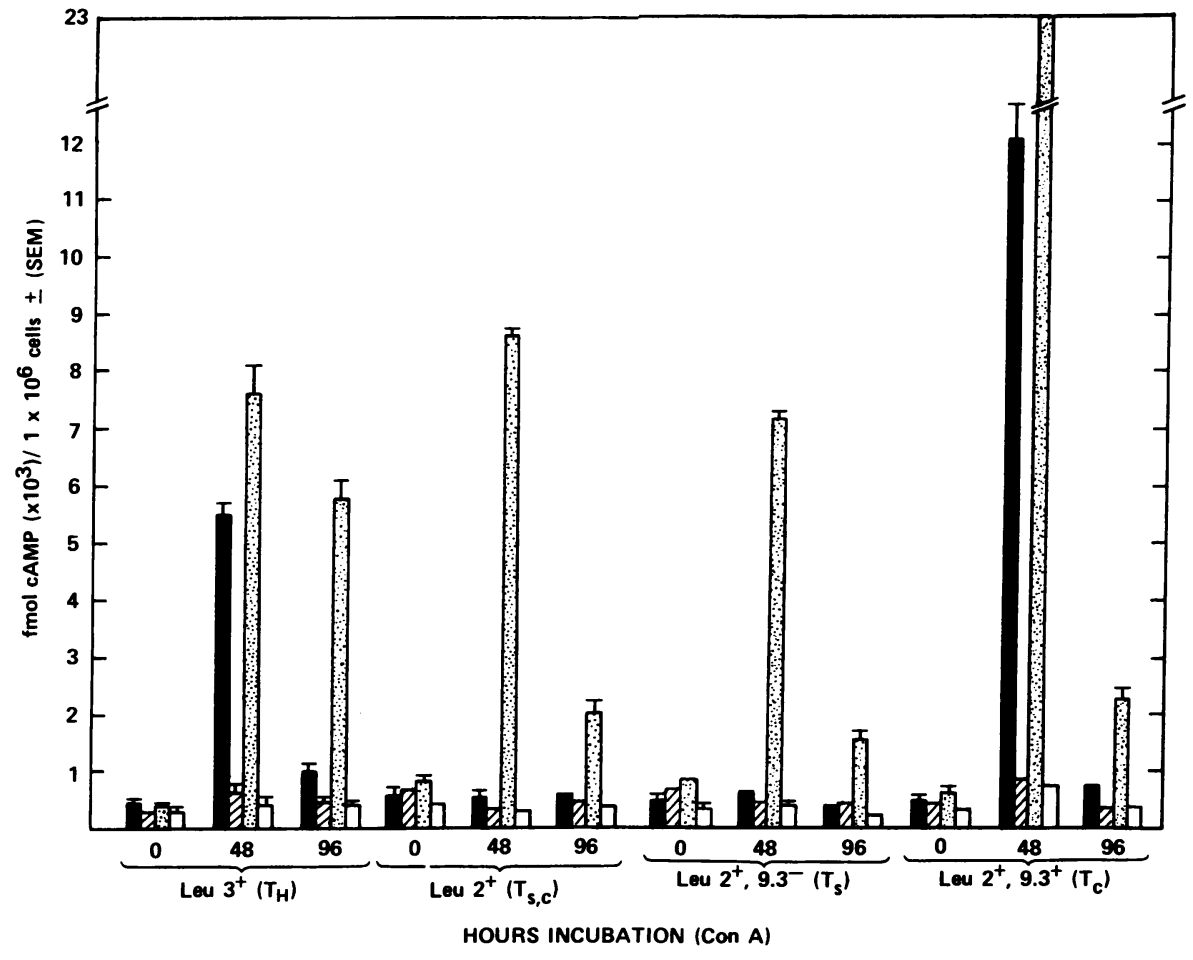

Figure 4. Effects of histamine $\left(10^{-4} \mathrm{M}\right)(\square)$, isoproterenol $\left(10^{-5} \mathrm{M}\right)(\square)$, or forskolin $\left(10^{-5} \mathrm{M}\right)(\mathrm{⿴囗十)})$ on intracellular accumulation of cAMP are shown after various periods of incubation of subsets of human $T$ cells with $25 \mu \mathrm{g} / \mathrm{ml}$ Con A and monocytes. Open bars represent basal levels of cAMP. Values are means of triplicates. Response to forskolin is significantly different $(P$ $<0.01$ ) in all Con A-treated subsets vs. untreated cells. Response to histamine is significantly different $(P<0.01)$ only in Leu $3^{+}$and Leu $2^{+}, 9.3^{+}$cells in Con Atreated vs. untreated cells. One representative experiment of four experiments is shown.

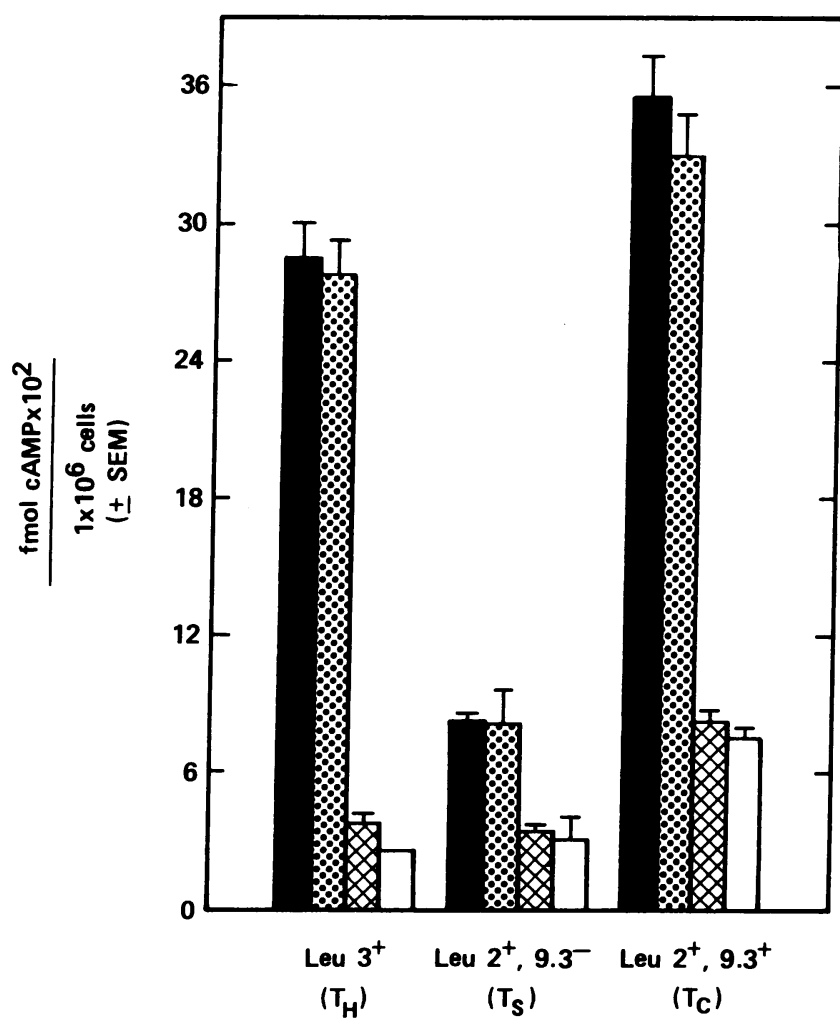

Figure 5. This figure shows the effects of an $\mathrm{H}_{1}$ antagonist, mepyramine $\left(10^{-6} \mathrm{M}\right)(\nabla)$, and an $\mathrm{H}_{2}$ antagonist, cimetidine $\left(10^{-5} \mathrm{M}\right)(\boldsymbol{\nabla})$, on intracellular accumulation of cAMP in PHA-stimulated subsets of $T$ cells in response to histamine $\left(10^{-4} \mathrm{M}\right)(\square)$. Open bars represent basal levels of cAMP. Each bar represents an average of triplicates \pm SEM in one representative experiment out of three experiments.

\section{Discussion}

The presence of receptors for autacoids on immunoregulatory $T$ cells $\left(T_{s}\right)$ was reported by Melmon et al. (16). The demonstration was largely based on the adherence of the cells to affinity columns constructed with conjugates of autacoids with albumin that were insolubilized on agarose beads. The present study evaluates the effects of autacoids on subsets of human $T$ cells in resting as well as mitogen-stimulated states.

The Leu $3^{+}$subset was isolated from peripheral blood using Leu 3 antibody. The Leu $2^{+}\left(3^{-}\right)$subset was further separated using 9.3 antibody into Leu $2^{+}, 9.3^{+}\left(T_{c}\right)$ and Leu $2^{+}, 9.3^{-}\left(\mathrm{T}_{3}\right)$ subsets. The Leu $3^{+}$subset includes most helper/

\section{PREPARATION OF HUMAN PERIPHERAL BLOOD IMMUNOCYTES}

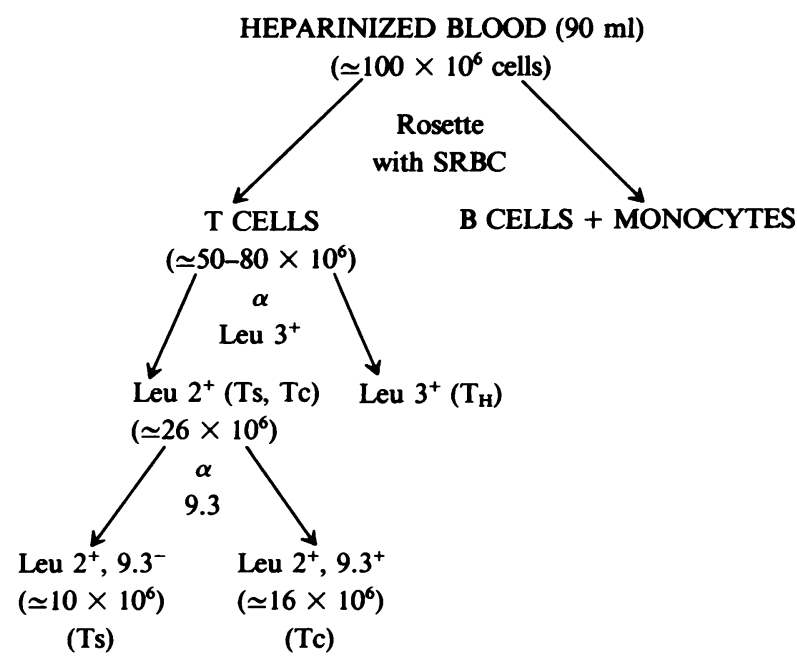


inducer cells, the Leu $2^{+}, 9.3^{-}$subset includes most $\mathrm{T}$ cells capable of suppressing immunity, and the Leu $2^{+}, 9.3^{+}$subset includes all or nearly all (HLA, A, B) class 1 major histocompatibility complex alloantigen-specific $T_{c}$ cells (10-12).

The pharmacologic response to histamine and isoproterenol was shared by most resting $\mathrm{T}$ cells. However, the rank order of potency of each of the two autacoids was specific to the given subset: Con A and PHA enhanced only the response to histamine and then only in selected subsets. The kinetics of the enhancement were also characteristic of a given subset. If we had performed these experiments only on unseparated $T$ cells we would not have observed either the apparent control of $T_{s}$ cells over the $T_{c}$ cells basal cyclic AMP or the remarkable selectivity of autacoid effects.

The selectivity of qualitative and quantitative responses to histamine and isoproterenol could be explained by a nonrandom distribution and density of receptors among subsets. In similar experiments using clones of murine $T$ cells we found distinct categories of responses to histamine and beta agonists that were peculiar to a given clone (16a). Some clones responded to both histamine and isoproterenol, others to either or neither agonist. These observations may further support the nonrandom nature of the distribution of receptors for autacoids on $T$ cell subsets. The selectivity in the responsiveness of different populations of $\mathrm{T}$ cells to beta adrenergic agonists and histamine had earlier been reported (17-19). Corticosteroid resistant murine thymocytes were less responsive to isoproterenol than untreated thymocytes. The latter were more responsive than lymphoid cells from spleen, lymph node, and blood (17). Niaudet et al. (19) reported that T lymphocytes isolated from human peripheral blood produced more cAMP in response to isoproterenol than $\mathrm{T}$ cells isolated from human tonsils and adenoids.

An alternative explanation for the selectivity of responses could be due to differences among cells in their degree of coupling of the receptors to the adenylate cyclase pool. We have observed that different populations of $T$ cells responded to forskolin in a selective fashion, which suggests that each subset contains a specific quantity of adenylate cyclase characteristic of that subset. In related studies we have found (16a) quantitatively additive effects of maximally effective doses of histamine and isoproterenol on cAMP accumulation in clones of mouse $T_{c}$ cells. These data offer an example of histamine and beta receptors that may be linked to separate and independent adenylate cyclase pools.

Activation of $\mathrm{T}$ cells with mitogen (PHA or Con $\mathrm{A}$ ) did not produce a significant change in basal levels of cAMP among the subsets. These data differ from reports $(20,21)$ that certain immunologic stimuli such as mitogens increased concentrations of intracellular cAMP.

Interestingly, culture of $\mathrm{T}$ cells with mitogens conditioned the response to one autacoid, histamine, but not to the other, isoproterenol. This conditioning occurred only in selected cells, the $T_{c}$ and $T_{H}$ subsets. The conditioning of responses through the $T_{c}$ and $T_{H}$ cells was both time and circumstance (cell mixture) dependent. Thus, the probable mechanisms of selective and organized responses to autacoids in vivo begin to emerge. After separation into Leu $3^{+}$and Leu $2^{+}$subsets, the response of Leu $3^{+}$cells to histamine was augmented severalfold, whereas there was no significant change in response among the Leu $2^{+}$subset. When Leu $2^{+}$cells were further separated into Leu $2^{+}, 9.3^{+}$and Leu $2^{+}, 9.3^{-}$subsets, the response to histamine among the Leu $2^{+}, 9.3^{-}$subset remained unaltered, whereas the response in the Leu $2^{+}, 9.3^{+}$subset was increased severalfold. We interpret these results as indicating that cells in the Leu $2^{+}, 9.3^{-}$subset may regulate the histamine response in $T_{H}$ and $T_{c}$ cells. Similar results were observed in the control of basal cAMP levels by $T_{s}$ cells. The specificity of altered autacoid responsiveness produced by mitogens is further illustrated by its mediation only via $\mathrm{H}_{2}$ receptors.

Forskolin stimulated the maximum possible cyclic AMP production in all mitogen-induced subsets. However, our forskolin data further suggest that mitogen stimulation does not nonspecifically increase the accumulation of cAMP caused by the two autacoids tested. The potentiation seemed unrelated to enhancement of increased availability of adenylate cyclase, because both autacoids would have been expected to potentiate the cAMP accumulation if such were the case, although only histamine did so in only selective subsets. We believe it must have worked either by increasing the number of $\mathrm{H}_{2}$ receptors or activating some other function associated with the receptorcyclase coupling. Thus our observations suggest that immunological stimuli have selective effects in stimulating responses to agonists. It is possible that these effects are mediated by intercellular mediators. Rocklin and others $(22,23)$ have reported that histamine-induced suppressor cells mediate their effects via release of soluble factors.

In related studies (13) we have found that the Leu $2^{+}, 9.3^{-}$ subset includes all histamine-inducible suppressor cells and that after treatment with histamine these cells inhibit both PHA-induced $T$ cell proliferation and pokeweed mitogeninduced $B$ cell differentiation. A histamine $\mathrm{H}_{2}$ receptor antagonist (cimetidine), but not an $\mathrm{H}_{1}$ receptor antagonist (mepyramine), blocked the induction of suppressor cells, which suggests that activation of Leu $2^{+}, 9.3^{-}$cells with histamine may be mediated by $\mathrm{H}_{2}$ but not by $\mathrm{H}_{1}$ receptors.

To our knowledge, regulation of histamine receptor-mediated cAMP production in cytolytic $T$ cells by $T_{s}$ cells has not been previously reported. Plaut et al. (24) suggested that lymphocytes mediating cellular immunity develop receptors for histamine as a function of time after immunization. They also found an increase in the inhibitory effects on the function of cytolytic cell action correlated with the enhanced responsiveness in production of cyclic AMP. $10 \mathrm{~d}$ after immunization, histamine caused only $\sim 10 \%$ inhibition of cytolysis, which gradually rose to $>50 \%$ by day 16 . In contrast, dibutaryl cAMP, cholera enterotoxin, isoproterenol, and prostaglandin E caused consistent inhibition of cytolytic activity regardless of time elapsed after immunization. These experiments suggest that the cytolytic mechanism itself is inhibited by cyclic AMP at all times, but that histamine receptors develop gradually on killer lymphocytes only after immunization.

We know that agents that elevate intracellular cAMP also alter the immunological activity of cells (6-8). The mechanisms by which cAMP affects the immune process are not clear. We believe that further understanding of the mechanisms by which the Leu $2^{+}, 9.3^{-}$subset modulates the expression or function of the $\mathrm{H}_{2}$ receptor will be helpful in understanding the role of the autacoids and the second messenger in immune processes.

The differential ability of the cells to respond allows a structural and dissectible sequence of predominant actions caused by a ubiquitous hormone. Understanding that sequence 
seems important if we are ever to use the autacoid prospectively to modulate immunity.

\section{Acknowledgments}

This work was supported by National Institutes of Health grants R01 HL26340, 5R01 CA24607, and 5P01 HL13108.

\section{References}

1. Bourne, H. R., L. M. Lichtenstein, K. L. Melmon, C. S. Henney, Y. Weinstein, and G. M. Shearer. 1974. Modulation of inflammation and immunity by cyclic AMP. Science (Wash. DC). 184:19-28.

2. Lichtenstein, L. M. The interdependence of allergic and inflammatory processes. 1976. In Molecular and Biological Aspects of the Acute Allergic Reaction. S. G. O. Johansson, K. Strandberg, and B. Uvnas, editors. Plenum Press, New York. 233-254.

3. Melmon, K. L., and P. A. Insel. 1977. Inflammatory and immune responses: cell individuality amidst ubiquitous hormonal signals. Johns Hopkins Med. J. 141:15-22.

4. Melmon, K. L., R. E. Rocklin, and R. P. Rosenkranz. 1981. Autacoids as modulators of the inflammatory and immune response. Am. J. Med. 71:100-106.

5. Rocklin, R. E. 1976. Modulation of cellular-immune responses in vivo and in vitro by histamine receptor-bearing lymphocytes. $J$. Clin. Invest. 56:1051-1058.

6. Burchiel, S. W., and K. L. Melmon. 1979. Augmentation of the in vitro humoral response by pharmacologic agents. I. An explanation for the differential enhancement of humoral immunity via agents that elevate cAMP. Immunopharmacology. 1:137-150.

7. Teh, H. S., and V. Paetkau. 1974. Biphasic effect of cyclic AMP on an immune response. Nature (Lond.). 250:505-507.

8. Henney, C. S., H. R. Bourne, and L. M. Lichtenstein. 1972. The role of cyclic $3^{\prime}, 5^{\prime}$-adenosine monophosphate in the specific cytolytic activity of lymphocytes. J. Immunol. 108:1526-1534.

9. Engleman, E. G., C. J. Benike, F. C. Grumet, and R. L. Evans. 1981. Activation of human T lymphocyte subsets: helper and suppressor/ cytotoxic $\mathrm{T}$ cells recognize and respond to distinct histocompatibility antigens. J. Immunol. 127:2124-2129.

10. Kotzin, B. L., C. J. Benike, and E. G. Engleman. 1981. Induction of immunoglobulin-secreting cells in the allogeneic mixed leukocyte reaction: regulation by helper and suppressor lymphocyte subsets in man. J. Immunol. 127:931-935.

11. Damle, N. K., N. Mohagheghpour, J. A. Hansen, and E. G. Engleman. 1983. Alloantigen-specific cytotoxic and suppressor T lymphocytes are derived from phenotypically distinct precursors. $J$. Immunol. 131:2296-2300.

12. Brooker, G., J. F. Harper, W. L. Terasaki, and R. D. Moylan.
1979. Radioimmunoassay of cyclic AMP and cyclic GMP. In Advances in Cyclic Nucleotide Research. G. Brooker, P. Greengard, and G. A. Robison, editors. Raven Press, New York. 10:1-33.

13. Sansoni, P., E. D. Silverman, M. M. Khan, K. L. Melmon, and E. G. Engleman. 1985. Immunoregulatory $T$ cells in man: histamine induced suppressor $T$ cells are derived from a Leu $2\left(T_{8+}\right)$ subpopulation distinct from that which gives rise to cytotoxic $\mathrm{T}$ cells. J. Clin. Invest. 75:650-656.

14. Gespach, C., F. Saal, H. Cost, and J.-P. Abita. 1982. Identification and characterization of surface receptors for histamine in the human promyelocytic leukemia cell line HL-60. Mol. Pharmacol. 22:547-553.

15. Johnson, C. L., H. Weinstein, and J. P. Green. 1979. Studies on histamine $\mathrm{H}_{2}$ receptors coupled to cardiac adenylate cyclase. Mol. Pharmacol. 16:417-428.

16. Melmon, K. L., Y. Weinstein, T. C. Poon, H. R. Bourne, G. M. Shearer, P. Coffino, and P. A. Insel. 1977. Receptors for low molecular weight hormones on lymphocytes. In Immunopharmacology. J. W. Hadden, R. G. Coffey, and F. Spreafico, editors. Plenum Press, New York. 331-356.

16a. Khan, M. M., K. L. Melmon, C. G. Fathman, B. HertelWulff, and S. Strober. 1985. The effects of autacoids on cloned murine lymphoid cells: modulation of IL-2 secretion and the activity of natural suppressor cells. J. Immunol. In press.

17. Bach, M. A. 1975. Differences in cyclic AMP changes after stimulation by prostaglandins and isoproterenol in lymphocyte subpopulations. J. Clin. Invest. 55:1074-1081.

18. Roszkowski, K., M. Plaut, and L. M. Lichtenstein. 1977. Selective display of histamine receptors on lymphocytes. Science (Wash. DC). 195:683-685.

19. Niaudet, P., G. Beaurain, and M. A. Bach. 1976. Differences in effect of isoproterenol stimulation on levels of cyclic AMP in human $B$ and T lymphocytes. Eur. J. Immunol. 6:834-836.

20. Plescia, O. J., I. Yamamoto, and T. Shimamura. 1975. Cyclic AMP and immune responses: changes in the splenic level of cyclic AMP during the response of mice to antigen. Proc. Natl. Acad. Sci. USA. 72:888-891.

21. Yamamoto, I., and D. R. Webb. 1975. Antigen-stimulated changes in cyclic nucleotide levels in the mouse. Proc. Natl. Acad. Sci. USA. 72:2320-2324.

22. Rocklin, R. E., D. K. Greineder, and K. L. Melmon. 1979. Histamine induced suppressor factor (HSF): further studies on the nature of the stimulus and the cell which produces it. Cell. Immunol. 44:404-415.

23. Garovoy, M. R., M. A. Reddish, and R. E. Rocklin. 1983. Histamine induced suppressor factor (HSF): inhibition of helper T cell generation and function. J. Immunol. 130:357-361.

24. Plaut, M., L. M. Lichtenstein, and C. S. Henney. 1973. Increase in histamine receptors on thymus-derived effector lymphocytes during the primary immune response to alloantigens. Nature (Lond.). 244: 284-287. 